\title{
LA LEY ELECTORAL DE 1951, DE LA REPRESENTACIÓN A LA ENCARNACIÓN
}

THE ELECTORAL LAW OF 1951 , FROM THE IDEA OF REPRESENTATION

TO THE IDEA OF INCARNATION

SABRINA AJMECHET ·

Sabrina Ajmechet es becaria post-doctoral del CONICET con sede en el Instituto de Historia Argentina y Americana «Dr. Emilio Ravignani» de la Universidad de Buenos Aires (Argentina).

\section{Resumen}

En la Argentina, dos leyes electorales consagraron un sistema de elección por circunscripciones uninominales para la designación de diputados para el Congreso de la Nación. La primera vez que se impuso fue en 1902 bajo el gobierno de Roca. La segunda fue en 1951, antes de los comicios que consagraron la reelección de Perón. En ambas ocasiones se eligió el mismo sistema electoral pero por motivos muy diferentes. En 1902 , los reformistas consideraron que en la sociedad se expresaban localmente intereses diversos que debían estar representados en el Congreso. El objetivo del peronismo fue otro: consagrar la unanimidad como ideal en el parlamento.

En 1951, el peronismo ya contaba con mayoría en ambas Cámaras. ¿Por qué buscó aumentar su representación en el Congreso si ya contaba con un número suficiente de diputados y senadores como para legislar a voluntad?
Calle 25 de mayo $n^{\circ} 217$ (Ciudad de Buenos Aires) E-mail: sabrina_ajmechet@yahoo.com.ar

\section{Abstract}

In Argentina, two electoral laws enshrined a system of election by single-member constituencies for the appointment of deputies to the National Congress. The first one was in 1902 under the government of Roca. The second one was in 1951, before the re-election of Peron. While the same electoral system was chosen on both occasions, the reasons were different. In 1902 the reformers considered that various interest layed throughout society and that these interests were expressed locally. They believed that the Congress was the institution where these interests should be represented. Peronism chose the system for a different reason: they intended to form an unannimous parliament.

In 1951, before sanctioning the new electoral law, the Peronist Party already had majority in both houses. Why did the they sought to increase their representation in Congress if they already had a sufficient number of deputies and senators to legislate at will? 